\title{
PELATIHAN PENGGUNAAN PROBIOTIK DAN IMUNOSTIMULAN UNTUK PENCEGAHAN DAN PENGOBATAN PENYAKIT IKAN LELE PADA KELOMPOK PEMBUDIDAYA IKAN ULAM ADI JAYA KABUPATEN MESUJI
}

\author{
Hilma Putri Fidyandini ${ }^{1 *}$, Yeni Elisidana², Nidya Kartini ${ }^{3}$ \\ Jurusan Perikanan dan Kelautan Universitas Lampung, Bandar Lampung \\ Jl. Prof. Sumantri Brojonegoro No.1 Bandar Lampung 35145 \\ Penulis Korespodensi : hilma.putri@fp.unila.ac.id
}

\begin{abstract}
Abstrak
Usaha budidaya ikan menunjukkan perkembangan yang pesat dari tahun ketahun. Hal ini dikarenakan semakin bertambahnya kesadaran masyarakat untuk mengkonsumsi ikan. Salah satu usaha budidaya yang banyak dilakukan masayarakat indunesia adalah budidaya ikan konsumsi air tawar. Teknologi budidaya ikan konsumsi air tawar yang saat ini banyak digunakan di Indonesia adalah sistem budi daya intensif dengan padat tebar yang tinggi. Sama seperti usaha budidaya perikanan lainnya, masalah utama dalam budidaya ikan air tawar adalah serangan penyakit. Untuk menghindari keadaan ini, perlu dilakukan upaya pencegahan dan penanggulangan penyakit secara tepat. Pencegahan penyakit ikan dapat dilakukan dengan cara peningkatan daya tahan tubuh ikan dengan pemberian imunostimulan alami. Imunostimulan alami yang mudah didapat di lingkungan sekitar antara lain kunyit, bawang putih, meniran, dan masih banyak lagi. Pencegahan penyakit juga dapat dilakukan dengan cara mengontrol kualitas air, baik dari suhu, kandungan oksigen terlarut, derajat keasaman, dan mengontrol jumlah bakteri pathogen dalam perairan. Kontrol jumlah bakteri dalam perairan biasanya dilakukan dengan pemberian probiotik. Sedangkan untuk pengobatan penyakit ikan dapat dilakukan dengan cara karantina ikan atau memisahkan ikan yang sakit dengan yang sehat dan juga pemberian obat-obatan alami. Aplikasi pemberian probiotik dan imunostimulan pada media budidaya dan pakan ikan lele mampu mencegah dan mengobati penyakit pada ikan lele sehingga mampu meningkatkan produksi ikan lele. Kendala yang dihadapi dalam budidaya ikan lele di Pokdakan Ulam Adi Jaya adalah kurangnya sarana dan prasarana budidaya terutama aerator.

Kata kunci: ikan lele, imunostimulan, probiotik.
\end{abstract}

\section{Pendahuluan}

Usaha budidaya ikan menunjukkan perkembangan yang pesat dari tahun ketahun. Hal ini dikarenakan semakin bertambahnya kesadaran masyarakat untuk mengkonsumsi ikan. Salah satu usaha budidaya yang banyak dilakukan masayarakat indunesia adalah budidaya ikan konsumsi air tawar. Teknologi budidaya ikan konsumsi air tawar yang saat ini banyak digunakan di Indonesia adalah sistem budi daya intensif dengan padat tebar yang tinggi. Sama seperti usaha budidaya perikanan lainnya, masalah utama dalam budidaya ikan air tawar adalah serangan penyakit. Kematian ikan dan kegagalan panen akan dialami jika serangan penyakit tidak ditanggulangi secara dini.

Upaya untuk mencegah ikan agar tidak terserang penyakit adalah dengan meningkatkan daya tahan tubuh ikan atau dengan mengontrol lingkungan budidaya. Peningkatan daya tahan tubuh ikan dapat dilakukan dengan pemberian pakan yang mengandung imunostimulan. Imunostimulan merupakan senyawa yang dapat meningkatkan daya tahan tubuh Mekanisme umum dari imunostimulan yaitu memperbaiki ketidakseimbangan sistem imun dengan cara meningkatkan imunitas spesifik maupun non spesifik.

Kontrol lingkungan budidaya dapat dilakukan dengan cara mengontrol kualitas air dan pemberian probiotik. Probiotik merupakan bakteri hidup yang memberikan pengaruh menguntungkan bagi inang dengan memodifikasi komunitas bakteri atau berasosiasi dengan inang, menjamin perbaikan dalam penggunaan pakan atau memperbaiki nutrisinya, memperbaiki respon inang terhadap penyakit atau memperbaiki kualitas lingkungannya (Verschuere et al. 2000). 
Mesuji merupakan salah satu kabupaten yang memiliki potensi perikanan budidaya yang cukup besar. Budidaya perikanan di Mesuji meliputi budidaya ikan air tawar, komoditas yang banyak digunakan diantaranya ikan lele, nila, patin, dan ikan mas, untuk mendukung berhasilnya budidaya tersebut sebaian besar pembudidaya membentuk kelompok pembudidaya yang disebut Pokdakan (kelompok pembudidaya ikan). Kabupaten Mesuji memiliki kurang lebih 50 Pokdakan, salah satu kelompok yang sukses berbudidaya adalah kelompok Ulam Adi Jaya yang ada di Desa Adi Luhur, Kecamatan Panca Jaya. Pokdakan Ulam Adi Jaya. Pokdakan ulam adi jaya terbentuk pada tahun 2016, dan sudah berbadan hukum pada tahun 2018. Pokdakan ini bergerak dalam tiga sektor yaitu pemijahan lele, pembesaran lele konsumsi, dan pembuatan pakan lele.

Usaha budidaya ikan di Mesuji terdiri dari pembenihan dan pembesaran. Masalah utama yang dihadapi adalah serangan penyakit pada benih ikan sehingga kematian yang cukup besar sering terjadi. Kematian ini menyebabkan menurunnya jumlah produksi ikan budidaya. Banyak faktor yang menyebabkan serangan penyakit pada ikan diantaranya faktor daya tahan tubuh ikan yang kurang baik, faktor lingkungan yang tidak optimal dan faktor pathogen yang berkembang di lingkungan budidaya sehingga menyebabkan penyakit. Oleh sebab itu perlu dilakukan pelatihan mengenai cara pencegahan dan pengobatan penyakit pada ikan budidaya.

Pencegahan penyakit ikan dapat dilakukan dengan cara peningkatan daya tahan tubuh ikan dengan pemberian imunostimulan baik alamai. Imunostimulan alami yang mudah didapat di lingkungan sekitar antara lain kunyit, bawang putih, meniran, dan masih banyak lagi. Berdasarkan penelitian Usy et al (2019) diketahui bahwa efektifitas kunyit (C. domestica Val) pada ikan bawal (Colosoma macropomum), selama dua minggu mampu memberikan pengaruh yang signifikan terhadap total leukosit ikan bawal ( $C$. macropomum), Pengaruh Pemberian Bawang Putih (Allium sativum) pada akan sebagai imunostimulan untuk meningkatkan respons imun non spesifik ikan lele dumbo (Clarias gariepinus) juga telah diteliti oleh Sulistyaningrum dan Riski Putri (2016) dan menunjukkan hasil yang berbeda nyata. Pencegahan penyakit juga dapat dilakukan dengan cara mengontrol kualitas air, baik dari suhu, kandungan oksigen terlarut, derajat keasaman, dan mengontrol jumlah bakteri pathogen dalam perairan. Kontrol jumlah bakteri dalam perairan biasanya dilakukan dengan pemberian probiotik. Sedangkan untuk pengobatan penyakit ikan dapat dilakukan dengan cara karantina ikan atau memisahkan ikan yang sakit dengan yang sehat. Pemberian obat-obatan alami juga dapat dilakukan untuk pengobatan ikan yang sakit.

Kegiatan ini bertujuan untuk meningkatkan pengetahuan Pokdakan di Mesuji tentang cara pencegahan dan pengobatan penyakit ikan yang mereka pelihara dengan menggunakan imunostimulan dan vaksin sehingga jumlah produksi meningkat. Setelah dilakukan kegiatan penyuluhan ini diharapkan Pokdakan mampu menerapkan dan mengaplikasikan cara pencegahan dan pengobatan penyakit ikan dengan menggunakan imunostimulan dan vaksin sehingga proses budidaya ikan akan berjalan dengan baik dan dapat meningkatkan jumlah produksi usaha budidaya.

\section{Bahan dan Metode}

Metode yang dilakukan antara lain metode pra kondisi Pendekatan ini dilakukan sebelum kegiatan utama berlangsung, metode ceramah dan diskusi dengan cara menyampaikan materi yang telah disusun dalam bentuk power-point, metode anjangsana dan anjangkarya Selama kegiatan dilakukan kunjungan kepada Pokdakan, baik di rumah (anjangsana) atau pun di tempat-tempat mereka biasanya melakukan kegiatan budidaya (anjangkarya). Bahan yang digunakan yaitu probiotik, imunostimulan, benih ikan lele, pakan. Alat yang digunakan yaitu DO meter, $\mathrm{pH}$ meter, spuit, botol plastik.

\section{Hasil dan Pembahasan}

Sebagian besar anggota kelompok Pokdakan Ulam Adi Jaya belum menerapkan probiotik dan imunostimulan pada kegiatan budidaya ikan lele. Hal ini disebabkan kurangnya pengetahuan tentang pentingnya pemberian probiotik dan imunostimulan untuk kesehatan ikan. Pengobatan ikan sakit yang selama ini Pokdakan lakukan adalah dengan pemberian antibiotik, sedangkan antibiotik saat ini harus dikurangi penggunaannya. Penggunaan antibiotik untuk pengobatan ikan dapat menyebabkan dampak negatif yaitu resistensi terhadap pathogen dan akan terakumulasi dalam tubuh ikan lele. 
Materi penyuluhan dibuat berdasarkan kebutuhan dan kepentingan pembudidaya dengan memperhatikan manfaat dan kelestarian sumber daya perikanan. Materi penyuluhan berisi unsur pengembangan sumber daya manusia dan ilmu pengetahuan. Untuk mengetahui kesesuaian materi dengan kebutuhan sasaran dan tujuan penyuluhan, Pokdakan mengisi kuisioner kesesuaian materi dengan menggunakan google form. Tabel 4 merupakan hasil kuisioner kesesuaian materi dengan tujuan penyuluhan perikanan.

Tabel 1. Kesesuaian materi dengan tujuan penyuluhan perikanan

\begin{tabular}{clcccc}
\hline No & Kriteria & Skor & $\begin{array}{c}\text { Jumlah } \\
\text { Respon } \\
\text { den }\end{array}$ & $\begin{array}{c}\text { Total } \\
\text { Skor }\end{array}$ & $\begin{array}{c}\text { Persentase } \\
(\%)\end{array}$ \\
\hline 1 & Sesuai & 3 & 15 & 45 & 83 \\
2 & Kurang & 2 & 4 & 8 & 17 \\
& sesuai & & & & \\
3 & Tidak & 1 & 0 & 0 & \\
& sesuai & & & & 100 \\
\hline
\end{tabular}

Berdasarkan tebel di atas menunjukkan 15 responden $(83 \%)$ menyatakan materi penyuluhan penggunaan probiotik dan imunostimulan untuk pencegahan dan pengobatan penyakit ikan lele sesuai dengan kebutuhan sasaran dan tujuan penyuluhan. Materi yang diberikan kepada pokdakan adalah segala sesuatu yang berkaitan dengan usaha perbaikan produksi benih, pendapatan, dan tingkat kesejahteraan anggota. Metode penyuluhan yang digunakan pada pelaksanaan penyuluhan dengan menggunakan metode kombinasi ceramah dan demonstrasi.

Metode ceramah merupakan metode yang digunakan untuk menyampaikan informasi kepada sasara pada suatu pertemuan dengan tujuan menyampaikan informasi yang tepat, cepat dan lengkap dengan suatu penjelasan yang mendalam. Metode demonstrasi merupakan metode yang menunjukkan suatu cara atau pembuktian suatu hasil kegiatan yang lebih baik dengan cara melakukan kegiatan praktik. Untuk mengetahui kesesuaian metode dengan tujuan penyuluhan dapat dilihat pada Tabel 2.

Berdasarkan Tabel 2, menunjukkan bahwa 16 responden $(89 \%)$ menyatakan bahwa metode yang digunakan sesuai dengan keadaan sasaran sedangkan sisanya yaitu $11 \%$ responden menyatakan kurang sesuai. Tujuan utama pemilihan metode penyuluhan adalah a) tercapainya tujun penyuluhan pembangunan perikanan secara efektif, efisien dan akuntabel, b) mendorong sasaran agar dapat belajar menolong dan mengorganisasikan dirinya dalam mengakses sumberdaya, teknologi, pasar maupun modal, c) mengembangkan kreativitas sasaran agar bias meningkatkan produktivitas usahanya guna mencapai kesejahteraannya sendiri, d) mempercepat proses adopsi inovasi teknologi perikanan, e) mempermudah penyampaian materi oleh penyuluh dalam pelaksanaan penyuluhan perikanan.

Tabel 2. Kesesuaian metode dengan tujuan penyuluhan

\begin{tabular}{|c|c|c|c|c|c|}
\hline No & Kriteria & Skor & $\begin{array}{c}\text { Jumlah } \\
\text { Respon } \\
\text { den }\end{array}$ & $\begin{array}{l}\text { Total } \\
\text { Skor }\end{array}$ & $\begin{array}{c}\text { Persentase } \\
(\%)\end{array}$ \\
\hline 1 & Sesuai & 3 & 16 & 48 & 89 \\
\hline 2 & $\begin{array}{l}\text { Kurang } \\
\text { sesuai }\end{array}$ & 2 & 3 & 6 & 11 \\
\hline 3 & $\begin{array}{l}\text { Tidak } \\
\text { sesuai }\end{array}$ & 1 & 0 & 0 & \\
\hline & Jumlah & & 19 & 54 & 100 \\
\hline
\end{tabular}

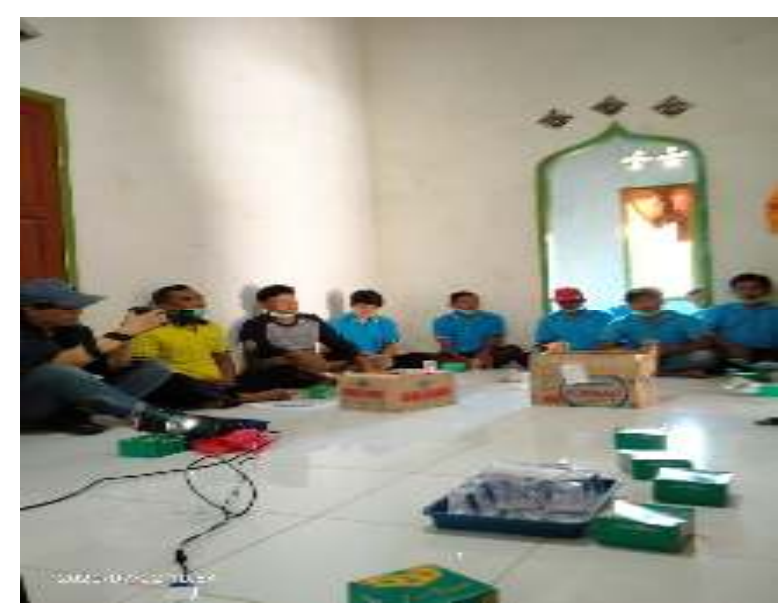

Gambar 1. Pelaksanaan penyuluhan mengenai probiotik dan imunostimulan

Praktek pemberian probiotik secara langsung dilakukan oleh kelompok pembudidaya yang didampingi oleh tim pengabdian masyarakat sehingga mereka mengetahui dosis yang harus diberikan, baik pada pakan maupun di air. 


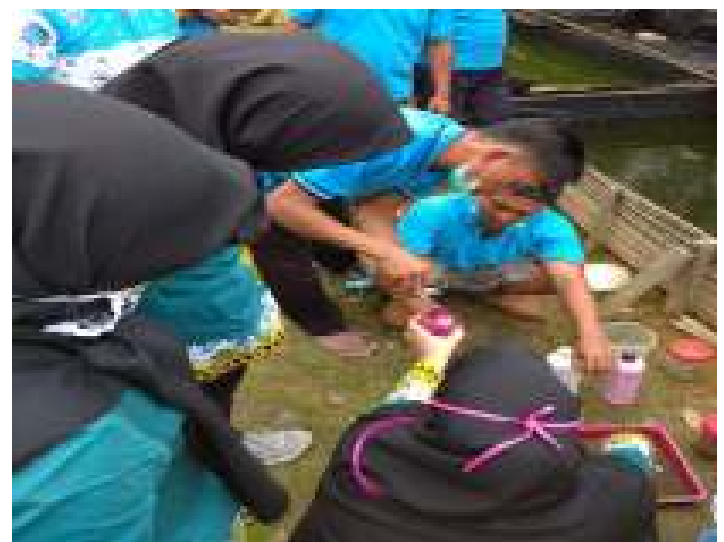

Gambar 2. Simulasi pemberian probiotik pada pakan ikan

\section{Kesimpulan}

Pelatihan dapat meningkatkan pengetahuan Pokdakan Ulam Adi Jaya Mesuji tentang cara pencegahan dan pengobatan penyakit ikan lele dengan imunostimulan dan probiotik.

\section{Ucapan Terima Kasih}

Ucapan terima kasih kepada Lembaga Penelitian dan Pengabdian Masyarakat (LPPM) Universitas Lampung yang sudah mendanai kegiatan pengabdian masyarakat ini melalui DIPA Universitas Lampung.

\section{Daftar Pustaka:}

Lusiastuti AM. (2010). Screening dan Aplikasi Probiotik untuk Pengendalian Penyakit Air Tawar. Seminar Hasil Penelitian. Balai Penelitian Perikanan Air Tawar. Bogor.

Ulistyaningrum, Riski P. (2016). Pengaruh Pemberian Bawang Putih (Allium Sativum) pada Pakan Sebagai Imunostimulan untuk Meningkatkan Respons Imun Non Spesifik Ikan Lele Dumbo (Clarias Gariepinus). Bachelor Thesis. Universitas Muhammadiyah Purwokerto.

Usy N. Manurung, Numisye, Mose. 2019. The use of turmeric, Curcuma domestica Val, as an immunostimulant in pomfret, Colossoma macropomum. Jurnal Budidaya Perairan Unsrat. Vol. 7 No. 1: 21-25.

Verschuere L, Rombaut G, Sorgeloos P, Verstraete W. 2000. Probiotics Bacteria as Biological Control Agents in Aquaculture. $J$ Microbiology and Molecular Biology Review. 64:655-671. 